VIII-1 | 2016

Dewey's Democracy and Education as a Source of and a Resource for European Educational Theory and Practice

\title{
The Influence of Dewey's and Mead's Functional Psychology Upon Veblen's Evolutionary Economics
}

\section{Guido Baggio}

\section{Q OpenEdition Journals}

\section{Electronic version}

URL: http://journals.openedition.org/ejpap/467

DOI: $10.4000 /$ ejpap.467

ISSN: 2036-4091

Publisher

Associazione Pragma

\section{Electronic reference}

Guido Baggio, «The Influence of Dewey's and Mead's Functional Psychology Upon Veblen's

Evolutionary Economics », European Journal of Pragmatism and American Philosophy [Online], VIII-1 | 2016, Online since 20 July 2016, connection on 30 April 2019. URL : http://

journals.openedition.org/ejpap/467; DOI : 10.4000/ejpap.467

This text was automatically generated on 30 April 2019.

\section{(c) (i) $\odot$}

Author retains copyright and grants the European Journal of Pragmatism and American Philosophy right of first publication with the work simultaneously licensed under a Creative Commons AttributionNonCommercial-NoDerivatives 4.0 International License. 


\title{
The Influence of Dewey's and Mead's Functional Psychology Upon Veblen's Evolutionary Economics
}

\author{
Guido Baggio
}

\section{AUTHOR'S NOTE}

An erlier version of this article was presented at the international colloquium "Economics and Psychology in Historical Perspective," held in Paris, December 18-20, 2014. The Author thanks the referees for the precious comments.

\section{Why is Economics not an Evolutionary Science?}

1 Since the second half of the 19th century, the natural and human sciences were charged with facing fresh questions raised by evolutionary theory. In particular, the human sciences needed to contend with the limits of their pre-Darwinian paradigms and to call into question the methodological and metaphysical assumptions that underlay them. In the United States, William James published the Principles of Psychology in 1890. Whilst James never abandoned his epochè concerning the causes of the phylogenetic evolution of human consciousness, evolutionism influenced his thought profoundly (James 1987). ${ }^{1}$ Integrating the results of recent research in physiology and animal psychology with philosophical reflections, James (1955: 2) advanced the idea that the faculty of mind "does not exist absolutely, but works under conditions." Mind has to be considered as a functional and dynamic element which selects stimuli from reality useful for the achievement of some immediate, as well as remote, ends, influencing the environment in which the subject lives (James 1955: 116 ss.). ${ }^{2}$ 
2 James' work on psychology re-invigorated work on the subject and, following him, John Dewey and George Herbert Mead, both at the University of Chicago from 1894, developed their psychological researches into human behavior undertaken in 1892 at the University of Michigan, laying the foundations for the Chicago School of Functional Psychology. Furthermore, in 1896 James R. Angell and Addison W. Moore undertook a psychological experiment on attention and habit under the guidance of Dewey and Mead (Angell \& Moore 1896).

3 The spirit of theoretical and methodological innovation which encouraged psychological and sociological studies at the University of Chicago involved all the departments of the University. In this innovative and stimulating environment, Thorstein Veblen, who joined Chicago in 1892 experienced what Hodgson describes as his academic epiphany. According to Hodgson (1998), Veblen's thought underwent an intellectual revolution during the years 1896-1899, stimulated by a number of debates in biology and social theory he assisted in during that period. ${ }^{3}$ It is not by chance that, between 1898 and 1899, he published, besides The Theory of the Leisure Class, a series of articles in which he criticized orthodox economic theories, highlighting their static and abstract nature and obsolescence and claiming for a methodological revolution in economics in favor of a paradigm shift which should heed recent psychology. ${ }^{4}$

4 In particular, in 1898 Veblen published an article against the taxonomic nature of orthodox economic science. He portrayed economists as "unable to handle its subject matter in such a way as to earn it standing as a modern science" (Veblen 1898a: 373). Veblen accused orthodox economic theories of being short-sighted for merely focusing upon material elements that compound economic institutions. Supported by a symbolic, often ambiguous, use of language, orthodox economics referred to a theoretical model rooted in some metaphysical assumptions which considered nature as the expression of a pre-ordered and aim-oriented structure, and that considered the human agent as an element of this system. Hence economic theories were rooted in a habit of thought that, through an expedient of abstract reason, referred to homo oeconomicus as inserted in a competitive system which elaborates fixed economic laws totally detached from the becoming of reality and of human actions.

5 From such a perspective, the theory was unable to catch the dynamic and evolving nature of the history of the individual's economic life, preferring to characterize it as a feat of scientific imagination (Veblen 1899b: 422-3). In other words, in lieu of being the product of a process of adaptation of means and ends subject to the becoming of human evolutionary processes, economics revealed it to be a deductive science which consolidated a mechanism of conservation of equilibrium reflecting a natural law order. This conservative, static representation of reality was legitimated by faith in a progre ssive cumulative tendency that had not been abandoned with the shift from the preDarwinian to the Darwinian perspective. Hence economic theories maintained unaltered the idea that a stability of causal law is the product of a process of gradual amelioration of the phenomena of social and economic sciences. The perspectives of classical economists since Smith could be defined as the perspective of a ceremonial adaptation:

The ultimate laws and principles which they formulated were laws of the normal or the natural, according to a preconception regarding the ends to which in the nature of things, all things tend. In effect, this preconception imputes to things a tendency to work out what the instructed common sense of the time accepts as the adequate or worthy end of human effort. It is a projection of the accepted ideal of conduct. This ideal of conduct is made to serve as a canon of truth, to the extent that the 
investigator contents himself with an appeal to its legitimation for premises that run back of the facts with which he is immediately dealing, for the "controlling principles" that are conceived intangibly to underlie the process discussed and for the "tendencies" that run beyond the situation as it lies before him. (Veblen 1898a: 382)

One instance of this way of conceiving knowledge was "conjectural history" in the classical treatment of economic institutions, as well as the affective metaphors for money, depicted as "the great wheel of circulation" (Smith 1904: II, 2, 26).

7 As noted by Veblen, such "figurative," "metaphoric," "inscrutable" linguistic forms were used as "ultimate terms" by economists aiming to construct theories such as those of money and wages, referring to their concrete implications just to corroborate their thesis. In so doing, Veblen continued,

the ways and means and the mechanical structure of industry are formulated in a conventionalized nomenclature, and the observed motions of this mechanical apparatus are then reduced to a normalized scheme of relations. (Veblen 1898a: 383)

The scheme becomes "spiritually binding on the behavior of the phenomena contemplated" and the permutations of a given segment of the apparatus are worked out "according to the values assigned the several items and features comprised in the calculation." This is the "deductive method," composed of

a body of logically consistent propositions concerning the normal relations of things - a system of economic taxonomy. At its worst, it is a body of maxims for the conduct of business and a polemical discussion of disputed points of policy. (Veblen 1898a: 384)

\section{Veblen's Notion of "Habit" between Peirce's Logic and James' Psychology}

9 What are we going to do about it?, asked Veblen. His reply was a plea for a methodological revolution in economics that seems now to be analogous to those implemented by Copernicus in the study of nature and Kant in epistemology. Such a methodological revolution consisted in shifting one's attention from material elements belonging to economic taxonomy, and clustered under the conceptual category of "capital," conceived as "a mass of material objects serviceable for human use" (Veblen 1898a: 387), to the human agent as the subject matter of the science. It is the human agent that changes, reflects, evaluates, selects the materials. The accumulation of materials already to hand conditions the utilization of material offered, but such a limitation pertains to what the human agent can do and their method of doing it. And the continuity of development is to be looked for in human material. It is the human agent who is the motor force of the process of economic development that thus needs to be studied by economic science. Such a new approach allows economics to become a social science which can reckon with the research results and studies of other human and natural sciences. The material objects are:

Substantially, prevalent habits of thought, and it is as such that they enter into the process of industrial development. The physical properties of the material accessible to man are constants: it is the human agent that changes - his insight and his appreciation of what these things can be used for is what develops. (Veblen 1898a: 387-8) 

mind." Whilst we do not find direct mention of Peirce's theory of logic in Veblen's writings, we know that Veblen was acquainted with Peirce's logic for he had assisted in Peirce's lessons in logic at John Hopkins University in 1881 (Dorfman 1935: 41). ${ }^{5}$

11 In 1877 Peirce had published The Fixation of Belief, in which he had defined the habit of mind as the result of an act of natural selection consisting in the capacities of human beings to elaborate inferences which validity is verified by their practical applications. In other words, human agents are able to select inferences useful to practical ends through a process of logical evaluation of the possible advantages of certain inferences rather than others. Hence the function of thought is to produce some habits of action and, consequently, the meanings of objects and ideas result from the appreciation of implied practical consequences. As Peirce argued:

We are, doubtless, in the main logical animals, but we are not perfectly so [...]. Logicality in regard to practical matters (if this be understood, not in the old sense, but as consisting in a wise union of security with fruitfulness of reasoning) is the most useful quality an animal can possess, and might, therefore, result from the action of natural selection; but outside of these it is probably of more advantage to the animal to have his mind filled with pleasing and encouraging visions, independently of their truth; and thus, upon unpractical subjects, natural selection might occasion a fallacious tendency of thought. (CP 5.366)

the inferential ability, Peirce's definition of human being as 'logical animal emphasizes characters influencing a person's beliefs and way of acting, namely her behavioral dispositions. As Peirce argued in How to Make Our Ideas Clear, "the whole function of thought is to produce habits of action" (CP 5.400). What a thing means is what habit of action it involves, and what the habit is depends on when it causes the person to act, that is when the perception causes the stimulus to action, and how it causes to produce some sensible result, that is some purpose of action. As Peirce puts it, "there is no distinction of meaning so fine as to consist in anything but a possible difference of practice" (CP 5.400).

is a more or less sure indication of there being some habits which will determine our actions that are embedded in our nature. What the habit is depends on when and how it causes us to act. As for the when, every stimulus to action is derived from perception; as for the how, every purpose of action is to produce some sensible result. Thus, we come down to what is tangible and conceivably practical, as the root of every real distinction of thought, no matter how subtle it may be.

According to Veblen, in this regard the human agent appreciates the material objects useful to their ends, that is to say, the human agent attributes meanings to things that they select as means for their ends. Veblen too, like Peirce, rejected causal mechanisms, in favor of the active dimension of human thinking and acting. ${ }^{6}$ Such active dimension is at the core of the evolutionary advancement of human reasoning in the fixation of beliefs which "guide our desires and shape our actions" (CP 5.371). As Griffin points out, then, Veblen is indebeted to Peirce for a social theory of logic "which envisioned the advancement of human reasoning from the tenacity of fixed beliefs to an education of attitudes and methods of science" (Griffin 1998: 750). ${ }^{7}$

15 If on the one hand Peirce's logic offered Veblen the notion of habits of thought and the general process of the fixation of beliefs, on the other, James' psychology offered Veblen the basis for a psychological explanation of the development of habits. In particular, 
James' functionalism offered him a psychological explanation of the differentiation of social ends and interests that accompany the changing processes of habits of thought.

More precisely, James distinguished between habits as instincts, effects of an innate tendency, and habits as acts of reason, "due to education," and defined habits as "the enormous fly-wheel of society, its most precious conservative agent" (James 1890: 79). ${ }^{8} \mathrm{At}$ the basis of this distinction is the core of James' hypothesis about human consciousness according to which the activation of consciousness is due to a "lucky chance," but by virtue of the hereditary influence of habits, in its choice of interests, a more and more unstable nervous system has been determined across generations. Hence consciousness had the power of exerting a constant pressure in the direction of survival, giving the organism the power of acceding to the modes in which consciousness has trained it (James 1983: 54). The development of habits is then strictly related to the moral problem of selecting the correct processes of habitual relationships strenuously resisting wrong alternatives. This is also true in the modification of knowledge processes and in the scientific theory as that of economics. In claiming to favor a 'reconstruction in economics,' Veblen referred implicitly to a Jamesian explanation of habits, arguing that:

The canons of knowledge are of the nature of habits of thought, and habit does not break with the past, nor do the hereditary aptitudes that find expression in habit vary gratuitously with the mere lapse of time. What is true in this respect, for instance, in the domain of law and institutions is true, likewise, in the domain of science. What men have learned to accept as good and definitive for the guidance of conduct and of human relations remains true and definitive and unimpeachable until the exigencies of a later, altered situation enforce a variation from the norms and canons of the past, and so give rise to a modification of the habits of thought that decide what is, for the time, right in human conduct. (Veblen 1900: 240-1)

Strongly reinforced by modern sciences, the changes in human life that industrial revolutions have generated, have divested the knowledge of non-human phenomena of that teleological self-directing life that was one imputed to them, reducing this knowledge to therms of opaque causal sequence. As Veblen argued, non-human phenomena have not been supplanted by the equally uncouth denomination of habits, propensities, aptitudes, and conventions, even if these notions are at the basis of a way of considering non-human phenomena in economic science. So it is necessary to shift attention to those human phenomena that appeal the psychological dimension of economic human conduct. And this is possible only if economic science adopts the idea of an undetermined science and an undetermined universe, the object of an explanation that would take steps from an inductive non-a priori approach and consider the evolution of habits of thought as the product of a process of adaptation in which some methodological assumptions about different forms of human knowledge are involved.

Veblen's references to functionalist psychology are present in both Why is Economics not an Evolutionary Science? and in The Preconceptions of Economic Science. Veblen refers to later psychology as biological, arguing that "the base of action - and economic action - at any step in the process is the entire organic complex of habits of thought that have been shaped by past process" (Veblen 1898a: 392-3).

19 Use of notions such as "organic activities," "propensities," "aptitudes" suggests not only Veblen's knowledge of James' psychology, but also that Veblen was acquainted with Dewey's work on the reflex arc concept in psychology (Dewey 1896) and probably also Dewey's $(1894,1895)$ and Mead's $(1895,2001)$ works on emotion as well as with the experiments on attention and habit that Angell and Moore (1896) refined at the 
University of Chicago in that period. ${ }^{9}$ There is no direct mention of these works in Veblen's writings of these years, nevertheless Veblen's conception of science and economic rationality seems to have been influenced more by Dewey's and Mead's theory of the "organic circuit" rather than James' functionalism. ${ }^{10}$

\section{Veblen's References to Dewey's and Mead's Functionalist Psychology} psychological functionalism, Dewey proposed a new psychological theory aiming to redirect the attention of experimental psychology from the ontological mind-body distinction to the 'organic relation' between stimuli and response considered from a functionalistic perspective. In particular, he denounced the dualistic perspective of that experimental psychology which considered psychical phenomena statically, and called for an interpretation of human sensations, thinking, and actions as stages of the human act. Rather than a mechanistic explanation of the relation stimulus-response, he advanced the idea of a "sensorial circuit" highlighting the organic nature of the sensemotor process in which stimulus, selection, and motor response are considered as intertwined and interdependent stages instead of discrete and separated elements. According to Dewey, stimuli are not prior to an organism's capacity to select them, for the distinction between stimulus and response presupposes a dynamic sensorial process through which the perceiving organism becomes aware of the sensible stimulus at the moment at which it is useful for the restoration of an interrupted act.

Whilst Dewey had in 1886 already suggested the idea of an "organic relation" between subject and object sustaining a 'proto-functionalistic' psychology (while still framed in an idealistic conceptual background), ${ }^{11}$ it was only after the reading of James' Principles of Psychology, together with the onset of the intellectual collaboration with Mead and the move to Chicago, that Dewey abandoned definitively the idealistic framework in order to embrace the functionalistic experimental approach to psychology. Between 1894 and 1895 he published two articles on the matter of emotions - "The Theory of Emotions: Emotional Attitude" and "The Theory of Emotions: The Significance of Emotion" - in which, using an almost completely functionalist conceptual apparatus, he sketched his own map of an organic theory of emotions. ${ }^{12}$

Actually, Dewey's theory of emotion was not his own product solely. Dewey himself admitted his debt to Mead concerning both the description of the relationship between vegetative functions and motor functions, and the hypothesis about non-human emotional attitudes. As he wrote to Angell in 1893:

Among other things next year, Mead and I are going to try to experiment on mental images, with a view to getting some results on attention and on rhythm. Mead is also trying to work out something on sensation on the biological side. All of us recognize, that sensation, especially its qualitative features, has been the sticking point to a successful statement of idealism. He is trying to see if one could get back of the present qualities and show the sensation as a condensation or precipitation of past organic activities, so that everything which is aesthetic now was once practical or teleological. I do not [if] this brief statement conveys the thought, but it seems to me one of the most important working hypotheses turned up lately. ${ }^{13}$ 
Dewey and Mead arrived at the University of Chicago in 1894, they worked on the formulation of a psychology which would include a theory of consciousness in terms of organic functions. In particular, they elaborated a phylogenetic hypothesis concerning consciousness from the sensory-motor processes, so overtaking both the limits of an idealistic interpretation of sensations and the risks of a reductionist physicalism. In other words, they searched for a psychology which had to be founded empirically. Their research produced a theory of emotion the aim of which was to overcome James' individualistic theory of emotion through a re-evaluation of the active role natural and social environments play in the emergence of emotions.

In particular, referring to both Darwin's and James' theories of emotions, Dewey argued that at the origin of emotion there is the interruption of an act and that the bodily expression of emotion is the expression of some attitudes of action "adjusted to some end" (Dewey 1895: 162). Dewey considered the expression of certain emotional attitudes as the marks of the passing over of emotional attitude into communicative gesture, ${ }^{14}$ arguing that there is a division between movements that are preparatory to a set of acts and movements that are useful in themselves as accomplished ends, the first being the expression of attitudes the culmination of which is the performance of the act. As he wrote:

Emotion in its entirety is a mode of behavior [my italics] which is purposive or has an intellectual content, and which also reflects itself into feeling or Affects, as the subjective valuation of that which is objectively expressed in the idea or purpose. (Dewey 1895: 170-1)

In other words, the emotion is aroused when the unification with activity is broken, calling for both a tension of intellectual recognition and the consideration of how to behave towards the object recognized:

The emotion is, psychologically, the adjustment or tension of habit and ideal, and the organic changes in the body are the literal working out, in concrete terms, of the struggle of adjustment. (Dewey 1895: 185) ${ }^{15}$

Dewey referred to 'behavior' as a pivotal element for the emotion. In particular, he indicated 'behavior' as "the ideal content of emotion" (Dewey 1895: 185). Behavior is then the center of the condensation of organic activities in which emotional attitude creates a tension between some behavioral habits and the ideal situations. ${ }^{16}$

A two-pages abstract of a paper Mead presented at the third annual meeting of the American Psychological Association of 1894 (Mead 1895), and other fragments on the relation between evolution, the development of intelligence, and the control of emotion, passion, or reflex action testify Mead's contribution to Dewey's theory. ${ }^{17}$ In these papers Mead proposed an explanation of organic activities tracing in their processes the passage from sensori-motor behavioral attitudes to reflections. More interested than Dewey in the biological processes, Mead was engaged from the beginning of his career in searching for a solution to the question concerning the phylogeny of consciousness, and in his contribution to Dewey's theory hypothesized that it was possible to find the passage from sensorial to symbolic stimulus in the qualitative differentiation of emotional tones expressed in the different instinctive attitudes.

According to Mead, the arousal of emotional tones of consciousness that lie in the physiological reply to symbolic stimuli connected to the rhythmical repetition of physiological stimulation. In particular, the rhythmical aspect which is at the basis of human actions ${ }^{18}$ represents the link between symbolic stimuli which have an aesthetic 
value expressed at the beginning in war and love dances in primitive populations and the instinctive acts at their basis. As Mead wrote:

It is under the influence of stimuli of this general character that the emotional states and their physiological parallels arise. The teleology of these states is that of giving the organism an evaluation of the act before the coordination that leads to the particular reaction has been completed. (Mead 1895: 164)

\subsection{Instinct, Behavior, and Social Evolution}

Dewey's and Mead's works inserted themselves into ongoing debates on the methodologies and notions to be used in the new science of empirical psychology. Since the publication of Theodor Fechner's Elemente der Psychophysik (1860), psychophysics had been proposing a natural method to measure the sensory stimulus-response mechanism, interpreting the intensity of the stimulus with causal physical laws. However, the debate around the psychophysical measurement did not yield useful results and pragmatists were aware of this. In 1885 Peirce and Jastrow published the results of experiments on small differences of sensation that showed the methodological limits of a psychophysical measurement of conscious states. Dewey (1887) also pointed out the limits of a psychophysical measurement in his review of Ladd's Elements of Physiological Psychology (the first American publication on physiological psychology). And in 1894 Mead accused physicists to do not consider the fact that the only way to trace the distinction between the psychical and the physical characters of perceptions was to distinguish "between the world as composed of means and of ends" (Mead 1894: 23; emphasis added), namely between sensations that are means acting as stimuli and "ends or purposes in consciousness" (Mead 1894: 23).

And if the psychological debate was not resolved, a fortiori it was not resolved in economics, as highlighted by Veblen. Analogously to psychophysics' reduction of the qualitative intensity of sensation to the quantitative magnitude of its physical stimulus, utilitarians reduced happiness to a calculus of pleasure and pain, considering intensity and its duration as the only dimension belonging properly to feeling and that intensity of feeling is the instantaneous state that determines the degree of utility. Hence they determine quantitatively its maximization "by purchasing pleasure, as it were, at the lowest cost of pain" (Jevons 1888: 23) and identifying "the physical objects or actions" with the source of pleasure and pains (Jevons 1888: 37). The background of such an economic framework was a methodological a priori approach to human conduct based upon the hedonistic psychological assumption that actual impulsions are effects of the "obscure" demand of pleasure. As in the psychophysics measurement the qualitative dimension of sensation was reduced to a stimulus-response causal law, in economics human action was seen as the product of environment causal forces and the individual was seen as a "mechanism of commutation." One of the consequences was the success of mechanistic and deterministic theories of human economic behavior. As Veblen argued:

The purpose of the valuation process through which the impulse is so conveyed, human nature may, therefore, be accepted as uniform; and the theory of the valuation process may be formulated quantitatively, in terms of the material forces affecting the human sensory and of their equivalents in the resulting activity. In the language of economics, the theory of value may be stated in terms of the consumable goods that afford the incentive to effort and the expenditure undergone in order to procure them. Between these two there subsists a necessary equality; but the magnitudes between which the equality subsists are hedonistic 
magnitudes, not magnitudes of kinetic energy nor of vital force, for the terms handled are sensuous terms. (Veblen 1899b: 414-5)

31 of the measurability of such an equality of magnitudes, although such an assumption was based only in a methodological and conceptual need. The associationist psychology at the basis of economic theory was in this respect highly inappropriate since it conceived man as a passive isolated datum:

The human material with which the inquiry is concerned is conceived in hedonistic terms; that is to say in terms of a passive and substantially inert and immutably given nature. The psychological and anthropological preconceptions of the economists have been those which were accepted by psychological and social sciences some generations ago. The hedonistic conception of man is that of a lightning calculator of pleasures and pains, who oscillates like a homogeneous globule of desire of happiness under the impulse of stimuli that shift him about the area, but leave him intact [...]. He is an isolated definitive human datum, in stable equilibrium except for the buffets of the impinging forces that displace him in one direction or another. (Veblen 1898a: 389)

Hence psychophysics had contributed to legitimate hedonism (utility) as a ground of legitimacy and a guide in the normalization of knowledge in economics and ethics (Veblen 1899b: 414 ss.).

However, as also Mead suggested already in 1894, physics needed to rethink the logical apparatus through which it looked at perceptual phenomena because, only by changing the logical apparatus, could it defeat its limits (limits that Mead (1903) later would extend to various psychological theories). Analogously, according to Veblen the reference to the notion of "organic activities" would help overcome the mechanistic approach to economic phenomena. He then referred explicitly to the "reflex arc" concept, in line with Dewey's and Mead's ideas about organic activity:

The causal sequence in the "reflex arc" is, no doubt, continuous; but the continuity is not, as formerly, conceived in terms of spiritual substance transmitting a shock: it is conceived in terms of the life activity of the organism. Human conduct, taken as the reaction of such an organism under stimulus, may be stated in terms of tropism, involving, of course, a very close-knit causal sequence between the impact and the response, but at the same time imputing to the organism a habit of life and a self-directing and selective attention in meeting the complex of forces that make up its environment. The selective play of this tropismatic complex that constitutes the organism's habit of life under the impact of the forces of the environment counts as discretion.

So far, therefore, as it is to be placed in contrast with the hedonistic phase of the older psychological doctrines, the characteristic feature of the newer conception is the recognition of a selectively self-directing life process in the agent. (Veblen 1900: 247)

Such a new conception refers to human agents not as calculators of pleasures and pain, but rather as acting teleologically, that is, as "a coherent structure of propensities and habits which seek realization and expression in an unfolding activity," while desires and attitudes under whose guidance the action take place are: "circumstances of temperament which determine the specific direction in which the activity will unfold itself in the given case" (Veblen 1898a: 390). By "circumstances of temperament," Veblen means those elements which specify the character of the individual. They are the "products of his hereditary traits and his past experience, cumulatively wrought out under a given body of traditions, conventionalities, and material circumstances" (Veblen 
1898a: 390). Also the main reference to temperament here is a pragmatist one, for James speaks of 'temperament' in various parts of his Principles, referring to attitudes of human character in terms of "balanced temperament," "irascible temperament," "emotional temperament," etc.

Hence the activity is the substantial fact of the process, whereas the individual

is but a single complex of habits of thought, and the same psychical mechanism that expresses itself in one direction as conduct expresses itself in another direction as knowledge. The habits of thought formed in the one connection, in response to stimuli that call for a response in terms of conduct, must, therefore, have their effect when the same individual comes to respond to stimuli that call for a response in terms of knowledge. The scheme of thought or of knowledge is in good part a reverberation of the scheme of life. (Veblen 1899: 143)

Veblen's references to notions such as "reflex arc," "organic activity," and "habit of thought," confirm that he was acquainted with Dewey's and Mead's psychology as the "later psychology" that would enable economic interests to be rooted in a social psychological dimension.

There are, therefore, some important affinities between the two perspectives, namely Dewey's and Mead's psychology, and Veblen's evolutionary economics. What is clear is the role functiontalist psychology played in Veblen's suggestions concerning a new approach to economics. ${ }^{19}$ What is less clear is the role the theory of emotion played in his ideas, even if, as we have seen, the same theory is at the base of organic circuit theory.

Nevertheless, Veblen's further development of human social agency seem to me to be consonant with Mead's explanation of the passage from emotion to social interest as well as with the general pragmatist approach to the problem-solving theory of human development.

According to Mead an emotion represents the correlation of instinctive stimuli to aesthetic stimuli and the common basis of the ontogeny and phylogeny of consciousness. Actually, Mead did not explain in his abstract that we analyzed above either the correlation between instinctive and aesthetic stimuli or the link between the latter as social stimuli (war and love dances) and the organism's response to it. Nevertheless, he did so in a fragment that seems to be the natural extension of the abstract I am analyzing and that Mead probably composed around $1896 .{ }^{20}$ In this fragment he suggested that, in the excessive emotional content expressed in acts such as those of war and love dances, and their individual expressions as rapine or pathological expressions of the sexual act, "we find in the first place that the distinction between them and other emotional expressions lies in the distinction between interest and passion of one sort or another." 21 Two things have to be explained here, that is, the presence of excessive emotional contents, and their relation to social developments. According to Mead, there is a distinction between 'interest' and 'passion' (the latter including all kinds of passion), regarding their difference in the expression of the emotional content. Emotional content is present in the former throughout the whole act and cannot be separated from it, whereas in the latter it absorbs the whole consciousness and, if the act is not accomplished, the emotion is still aroused. The progress of more controlled actions consists in transforming potential reflex actions - expressions of strong emotional power - into actions characterized by interest and not by passion. The possibility of further advancement is attained "through the socializing of processes which have been strictly individual up to this point." 22 
40 The distinction between 'interest' and 'passion' marks the dividing line between individual instincts connected to immediate consummation of needs and the social instincts - e.g the urge to fight is an outgrowth of the process of food consumption, that is, a socializing process of something primarily individual. ${ }^{23}$

41 It is noteworthy that at this time Mead was already taking his first steps towards a social perspective in psychology and that, even if Dewey was aware of the need for a "theory of consciously organic activity" to explain the organism's biological function of adaptation to natural environment, ${ }^{24}$ for his part, Mead was moving in that direction and perhaps this would better contribute to Veblen's idea of "biological psychology."

42 Now, as Veblen argued in line with Mead's theory, the responding organism is an "agent" whose intelligent behavioral response to stimulus is of a teleological character and that intelligence is "of the nature of an inhibitive selection" (Veblen 1919: 6). The human process of the evolution of habits and dispositions begins hence with the interruption of an act and the reply to social and natural stimuli through an interaction that is not merely mechanical:

Like other animals, man is an agent that acts in response to stimuli afforded by the environment in which he lives. Like other species, he is a creature of habit and propensity. But in a higher degree than other species, man mentally digests the content of the habits under whose guidance he acts, and appreciates the trend of these habits and propensities. He is in an eminent sense an intelligent agent. By selective necessity he is endowed with a proclivity for purposeful action. He is possessed of a discriminating sense of purpose, by force of which all futility of life or of action is distasteful to him. There may be a wide divergence between individuals as regards the form and the direction in which this impulse expresses itself, but the impulse itself is not a matter of idiosyncrasy, it is a generic feature of human nature. (Veblen 1898b: 188-9)

43 And as Veblen repeated some years later, human instincts leave the field open for adaptation of behavior to circumstances. In man "habit takes on more of a cumulative character, in that the habitual acquirements of the race are handed on from one generation to the next by tradition, training, education" (Veblen 1914: 38-9). Once the habits are acquired under given circumstances and impulses, a given line of behavior becomes habitual and so installed by use as a principle of conduct handed down by community (Veblen 1914: 50). These habits are, in other words, the rules under whose the institutions arise. Institutions, in fact, have the nature of prevailing habits of thought reflecting habits of life embedded in institutional structures of society, they hence are mental attitudes that are settled and prevalent, ${ }^{25}$ being at the basis of men's ordering their lives. ${ }^{26}$ Economic life is identified with community life, for it contributes to shape conventions and ways of social life. However, economic development also influences the evolutionary processes of culture, shaping a complex organism of habits and personalities.

As Veblen argued, in a sense in line with Dewey's and Mead's psychology, economic interest is a social interest as are aesthetic, sexual, humanitarians, and religious interests:

Since each of these passably isolable interests is a propensity of the organic agent man, with his complex of habits of thought, the expression of each is affected by habits of life formed under the guidance of all the rest. There is, therefore, no neatly isolable range of cultural phenomena that can be rigorously set apart under the head of economic institutions, although a category of "economic institutions" may be of service as a convenient captation, comprising those institutions in which the economic interest most immediately and consistently finds expression, and 
which most immediately and with the least limitation are of an economic bearing.

(Veblen 1898a: 393)

According to Veblen, the economic history of individuals and social groups is the product of a cumulative trend of adaptation between means and ends. This strongly contrasted with the utilitarian perspective, according to which society is the sum of individuals. On the contrary, the perspective inversion from an individualistic to a social approach would overcome the idea that economic interests are only individual interests. As Veblen argued, the consequence of the transition to the new conception of human nature construed in terms of functioning is that the newer view formulates conduct in terms of personality, whereas the earlier view was content to formulate it in terms of its provocation and its by-product (Veblen 1900: 248). ${ }^{27}$

\section{Conclusion}

In the works that Veblen published at the University of Chicago we find a curious blend of Peirce's logical approach and a pragmatist conceptualization of human conduct that has its roots, besides James' functionalism, in Dewey's and Mead's functionalism. It seems that some of Veblen's ideas are consonant with what Dewey and Mead were working on at the time. As it has been noted Veblen developed his theory of intelligent human conduct in the behavioral setting of stimulus and response. However, it was not a reductionist approach to human behavior, namely a sort of Watsonian behavioristic approach in which reason is reduced to a mere chooser's rationality (Kilpinen 1999: 199), rather much more a Dewey's and Mead's pragmatic behavioral approach to human conduct in wich reflective reasoning is part of the transaction between organism and environment. It is for that reason that I choosed to focus on the period 1896-1900 mainly, because the period represents in my view a high water mark in the influence of Dewey's and Mead's psychology on Veblen's thought. Hence it is possible to better comprehend the theoretical framework Veblen referred to when elaborating his first ideas of an evolutionary economics. It is also easier to understand why he rejected both the individual and society as the ultimate unity of explanation in the social sciences, searching for a balance between these two extremes.

Although he has sometimes used improperly psychological notions such as 'instinct,' 'habits of thought,' 'dispositions,' 'aptitudes,' etc., ${ }^{28}$ he used these notions as a framework in which insert his reflections upon economic institutions and social change. Moreover, such ambiguity on the use of psychological notions was due to the fact that, at the time, empirical psychology was taking its first steps. It was not a discipline with methodological and conceptual autonomy. Functionalism was still dependent upon natural sciences and methaphysics. ${ }^{29}$ One should bear in mind that concepts such as 'instinct' and 'behavior' at the time meant something different from what they would mean decades after.

Veblen's evolutionary economics has to be included with Dewey's and Mead's psychology among those post-Darwinian non-reductionist interpretations of the bio-psycho-social nature of human conduct. On the one hand, Veblen's call for a change of methodological paradigm brought in light the fallacy of the fact/value dicothomy; on the other hand, he gave voice to the need for a methodological renewal process beginning from a organic interpretation of human behavior and formation of habits. ${ }^{30}$ 


\section{BIBLIOGRAPHY}

ANGELL J. R., \& A. W. MOORE, (1896), "Studies from the Psychological Laboratory of the University of Chicago: 1. Reaction-Time: A Study in Attention and Habit," Psychological Review 3, 245-58. BACKE A., (2001), "John Dewey and Early Chicago Functionalism," History of Psychology, 4 (4), 323-40.

Backhouse R E., (1994), “The Fixation of Econoic Belief,” Journal of Economic Methodology, 1, 1, 33-42.

BAGGIO G., (2011), “The Mind/Brain Relation. From James... to James,” Salesianum, 73, 781-91.

BAGGIO G., (2015), La mente bio-sociale. Filosofia e psicologia in G. H. Mead, Pisa, ETS.

BALDWIN J. D., (1992), “Social Behaviorism on Emotions: Mead and Modern Behaviorism

Compared," in Hamilton P., (ed.), George Herbert Mead. Critical Assessments, vol. III, New York, Routledge, 237-63.

BARBAlet G., (2008), “Pragmatism and Economics: William James' Contribution," Cambridge Journal of Economics 32, 797-810.

CAMic C., (1986), “The Matter of Habit,” American Journal of Sociology, 91, 1039-87.

соок G. A., (1993), George Herbert Mead. The Making of a Social Pragmatist, Urbana and Chicago, University of Illinois Press.

DEWEY J. M., (1951), “Biography of John Dewey,” in Schilpp P. A., (ed.), The Philosophy of John Dewey, New York, Tudor Publishing Company.

DEWEY J., (1967 [1887]), Professor Ladd's Elements of Physiological Psychology, in John Dewey: The Early Works, vol. 1, edited by J. A. Boydston, Carbondale, IL, Southern Illinois University Press.

DEWEY J., (1971 [1894a]), “Review of Lester F. Ward's The Psychic Factors of Civilization,” in John Dewey: The Early Works, vol. 4, edited by J. A. Boydston, Carbondale, IL, Southern Illinois University Press.

DEWEY J., (1971 [1894b]), “The Theory of Emotion. I. Emotional Attitudes,” in John Dewey: The Early Works, vol. 4, edited by J. A. Boydston, Carbondale, IL, Southern Illinois University Press.

DEWEY J., (1971 [1895]), “The Theory of Emotion. II. The Significance of Emotions,” in John Dewey: The Early Works, vol. 4, edited by J. A. Boydston, Carbondale, IL, Southern Illinois University Press. DEWEy J., (1972 [1896]), “The Reflex Arc Concept in Psychology,” in John Dewey: The Early Works, vol. 5, edited by J. A. Boydston, Carbondale, IL, Southern Illinois University Press.

DEWEY J., (1973 [1929]), Experience and Nature, in John Dewey: The Later Works, vol. 1, edited by J. A. Boydston, Carbondale, IL, Southern Illinois University Press.

DORFMAN J., (1935.), Thorstein Veblen and His America, New York, The Viking Press.

DUGGER W. M., (1979), “The Origins of Thorstein Veblen's Thought,” Social Science Quarterly, 60, 3. DYER W., (1986), "Veblen on Scientific Creativity: The Influence of Charles S. Peirce," Journal of Economic Issues, XX, 1, 21-41. 
fOnTANA A., TILMAN R., \& L. ROE, (1992), “Theoretical Parallels in George H. Mead and Thorstein Veblen," The Social Science Journal, 29, 3, 241-57.

FRANZESE S., (2009), Darwinismo e Pragmatismo. E altri studi su William James, Milano-Udine, Mimesis. GARRISON J., (2003), “Dewey's Theory of Emotions: The Unity of Thought and Emotion in Naturalistic Functional 'Co-ordination' of Behavior," Transactions of the Charles S. Peirce Society, XXXIX, 3, 405-43.

GRIFFIN R., (1986), “Thorstein Veblen: The Theory of Evolutionary Economics as a Social Science," Rivista internazionale di scienze economiche e commerciali, 33, 12, 1150-63.

GRIFFIN R., (1992), "Front Door/Back Door Economics: The Origins of Veblenian Theory in the Epistemology of William James," Rivista internazionale di scienze economiche e commerciali, 39, 7, 569-83.

GRIFFIN R., (1998), "What Veblen Owed to Peirce - The Social Theory of Logic," Journal of Economic Issues, XXXII, 3, 733-57.

HALL J., \& O. WhyBrow, (2008), "Continuity and Continuousness: The Chain of Ideas Linking Peirce's Synechism and Veblen's Cumulative Causation," Journal of Economic Issues, XLII, 2, 349-55. HODGSON G. M., (1998), “On the Evolution of Thorstein Veblen's Evolutionary Economics,” Cambridge Journal of Economics, 22 (4), 415-31.

HODGSON G. M., (2004), “Reclaiming Habit for Institutional Economics,” Journal of Economic Psychology, 25, 651-60.

JAMES W., (1955 [1890]), Principles of Psychology, Chicago, Encyclopaedia Britannica Inc.

JAMEs W., (1983 [1878]), “Are We Automata?,” in Essays in Psychology, Cambridge, MA, Harvard University Press.

JAMEs W., (1983 [1884]), "What is an Emotion," in Essays in Psychology, Cambridge, MA, Harvard University Press.

JAMES W., (1984 [1892]), Psychology: Briefer Course, Cambridge, MA, Harvard University Press.

JAMES W., (1987 [1868]), “Two Reviews of The Variation of Animals and Plants under Domestication, By Charles Darwin," in Essays, Comments, and Reviews, Cambridge, MA, Harvard University Press.

JEvons W. S., (1888), The Theory of Political Economy, London-New York, MacMillan.

KILPINEN E., (1999), “What is Rationality? A New Reading of Veblen's Critique of Utilitarian Hedonism," International Journal of Politics Culture and Society, 13, 2, 187-206.

KILPINEN E., (2003), “Clarence Ayers Memorial Lecture. Does Pragmatism Imply Institutionalism?,” Journal of Economic Issues, XXXVII, 2, 291-304.

LAWLOR M. S., (2006), “William James's Psychological Pragmatism: Habit, Belief, and Purposive Human Behaviour," Cambridge Journal of Economics 30, 321-45.

LAWson T., (2015), "Process, Order and Stability in Veblen," Cambridge Journal of Economics 39, 993-1030.

LIEBHAFSKY E. E., (1993), “The Influence of Charles Sanders Peirce on Institutional Economics,” Journal of Economic Issues, XXVII, 3, 741-54.

MAYBARRY T. C., (1969), "Thorstein Veblen on Human Nature," American Journal of Economics and Sociology, $28,3$. 
MEAD G. H., (1894), "The Problem of Psychological Measurement," Proceedings of the American Psychological Association, New York, MacMillan \& Co., 22-23.

MEAD G. H., (1895), “A Theory of Emotions from the Physiological Standpoint (Abstract of a paper read to the Third Annual Meeting of the American Psychological Association, 1894)," Psychological Review, 2, 162-4.

MEAD G. H., (1903), “The Definition of the Psychical," Decennial Publications of the University of Chicago, First Series, vol. III, Chicago, University of Chicago, 77-112.

MEAD G. H., (1904), “The Relation of Psychology and Philology,” Psychological Bulletin 1, 375-91.

MEAD G. H., (1934), Mind, Self and Society, Chicago, University of Chicago Press.

MEAD G. H., (1936), Movements of Thought in the Nineteenth Century, Chicago, University of Chicago Press.

MEAD G. H., (2001), Essays in Social Psychology, Edited with an introduction by M. J. Degaan, New Brunswick, NJ, Transaction Publishers.

MILLER D. L., (1973), George Herbert Mead, Self, Language and the World, Chicago, The University of Chicago Press

NABERS L., (1958), "Veblen's Critique of the Orthodox Ecoonomic Tradition," in Dowd D. F., (ed.), Thorstein Veblen: A Critical Reappraisal, Ithaca, NY, Cornell University Press.

PANKSEPP J., (2001), “The Neuro-evolutionary Cusp between Emotions and Cognition,” Evolution and Cognition 7, 141-63.

PEIRCE C. S., (1877), “The Fixation of Belief,” in Collected Papers, vol. 5, edited by Harthsorne \& P. Weiss, Cambridge, MA, Harvard University Press, 1934, 358-87.

PEIRCE C. S., (1878), “How To Make Our Ideas Clear," in Collected Papers, vol. 5, edited by Harthsorne \& P. Weiss, Cambridge, MA, Harvard University Press, 1934, 388-410.

PEIRCE C. S. \& J. Jastrow, (1885), “On Small Differences of Sensation,” P 303, Memoirs of the National Academy of Sciences 3, 75-83.

PRATTEN S., (2015), “Dewey on Habit, Character, Order and Reform," Cambridge Journal of Economics $39,1031-52$.

RAYMER E. J., (2013), “A Man of His Time: Thorstein Veblen and the University of Chicago Darwinists," Journal of the History of Biology, 46, 4, 669-98.

SMITH A., (1904 [1776]), An Inquiry into the Nature and Causes of the Wealth of Nations, London, Metheun \& Co. Ltd.

TILMAN R., (1996), The Intellectual Legacy of Thorstein Veblen: Unresolved Issues, Westport, CT, Greenwood Press.

TILMAN R., (1998), “John Dewey as User and Critic of Thorstein Veblen's Ideas,” Journal of the History of Economic Thought, 20, 2, 145-60.

TILMAN R., (2007), Thorstein Veblen and the Enrichment of Evolutionary Naturalism, Columbia and London, University of Missouri Press.

TWORNEY P., (1998), “Reviving Veblenian Economic Psychology," Cambridge Journal of Economics 22, $433-48$.

VEBLEN T., (1884), “Kant's Critique of Judgment," The Journal of Speculative Philosophy, 18, 3, 260-74. 
VEBLEN T., (1891), "Some Neglected Points in The Theory of Socialism," Annals of the American Academy of Political and Social Science 2, 57-74.

VEBLEN T., (1898a), “Why is Economics not an Evolutionary Science?," Quarterly Journal of Economics, 12, 4, 373-97.

VEBLEN T., (1898b), “The Instinct of Workmanship and the Irksomeness of Labor,” American Journal of Sociology, 4, 2, 187-201.

Veblen T., (1899a), “The Preconceptions of Economic Science. Part I,” The Quarterly Journal of Economics, 13, 2, 121-50.

VEBLEN T., (1899b), “The Preconceptions of Economic Science. Part II," The Quarterly Journal of Economics, 13, 4, 396-426.

VEBLEN T., (1900), “The Preconceptions of Economic Science. Part III,” The Quarterly Journal of Economics, 14, 2, 240-69.

VEBLEN T., (1914), The Instinct of the Workmanship and the State of the Industrial Arts, New York, MacMillan.

VEBLEN T., (1919 [1906]), The Place of Science in Modern Civilization, in Id., The Place of Science in Modern Civilization and Other Essays, New York, B. W. Huebsch.

VEBLEN T., (1919 [1909]), The Limitations of Marginal Utility, in Id. 1919 [1906].

WALLER W. T. Jr., (1988), "The Concept of Habit in Economic Analysis," Journal of Economic Issues, XXII, 1, 113-6.

WATson J. B., (1913), “Psychology as the Behaviorist views it," Psychological Review, 2/20.

\section{NOTES}

1. For a critical review of James's receipt of Darwin's theory see Franzese 2009.

2. On this aspect see Baggio 2011.

3. In particular, according to Hodgson (1998), Veblen elaborated his ideas concerning a nonreductionist evolutionary economics under the influence of Peirce and James as well as being indirectly shaped by Cowny Lloyd Morgan who in 1896 gave a lecture on the author of Habit and Instinct at the University of Chicago. Morgan's thesis that human evolution occurred mainly at a socio-economic emergent level not explicable in terms of the biological characteristics of the individuals involved influenced Veblen's ideas on the evolutionary process of the selection of institutions. Lawson (2015: 1019-22) suggests that during his life Veblen changed his reference to evolution theory, passing from referring to a natural selection to a process of behavioral habituation due to his passage from a initial influence by the evolutionary writings of Herbert Spencer (in the Leisure Class) to a more Darwinian one. However, though it has been claimed that in his period in Chicago Veblen was mainly influenced by Jaques Loeb's reductionist meccanicist Darwinism, to which the influence of Peirce and James joined as a result of Veblens' moving away from the biological reductionism of Spencer (Hodgson 1998: 417), both a careful analysis of the terms and expressions used by Veblen's works of these years and a comparison with Dewey's and Mead's preceding writings will show some other elements of the influences on his thinking. In particular, the notion of habit is also at the basis of Peirce's logic as well as Dewey's and Mead's functionalism they were elaborating in those very years. On the Darwinist influence on Veblen's evolutionary economics, see also Raymer 2013. 
4. For a reconstruction of Veblen's analysis of orthodox economics see Nabers (1958: 77-111). For a comparison of Mead's and Veblen's ideas, see the third chapter of Tilman 1996; and Fontana, Tilman, \& Roe 1992. The work of Fontana et al. is interesting, but it considers mainly Mead's posthumous works that offer a more sociological and philosophical (and in a certain manner imperfect) interpretation of Mead's thought. Such kind of reading does not see Mead's theory of the Self as continuous with his psychological studies and reflections developed since his early collaboration with Dewey from 1890s. Such a comparison would offer a new perspective from which to look at some common elements between Mead's psychology and Veblen's first elaboration of evolutionary economics. I work on this point in Baggio 2015.

5. On Peirce's influence upon Veblen's thought see Kilipinen 1999, 2003; Griffin 1998; Liebhafsky 1993; and Hall \& Whybrow 2008.

6. On the relationship between Peirce's theory of scientific creativity and evolutionary economics of Veblen see Dyer (1986). For a comparison between Veblen's ideas and Peirce's mathematical concerns as well as his alleged belief in laissez faire capitalism see Kilpinen (1999: 192-5). Though I agree with Kilpinen's idea that Veblen's conception of rationality refers to Pierce's logic (Kilpinen 2003: 298-300), I also suggest in this article that his notion of human conscious and intelligent behavior is well rooted in the psychological and anthropological framework of the Chicago functionalism of Dewey and Mead.

7. On Peirce's thought applied to the methods of fixation of economic belief see the interesting article of Backhouse (1994).

8. Cf. Griffin 1992, 1986. On James' contribution to economics, see Lawlor 2006; and Barbalet 2008. 9. In their article Angell and Moore credit both Dewey and Mead with the guidance that provided the interpretation presented in the article.

10. The intellectual relationship between Dewey and Mead has been interpreted in controversial ways, in particular in reference to the foundation of the Chicago School of functionalism. Gary Cook (1993), for instance, considers Dewey to be the founder of functionalism, from which Mead elaborated his social psychology. David L. Miller (1973) has contended that the insights that form the foundation of functionalist psychology are Mead's, and that Dewey adopted the ideas from his friend and colleague. Miller's interpretation has been partially confirmed also by Dewey's daughter (Dewey 1951: 26). Whilst I have difficulty accepting one side of this contention, it can be reasonably inferred from the crediting of both Dewey and Mead a collaborative effort to develop the key ideas of functionalism. On this point see Baggio (2015: 15-29).

11. According to Andrew Backe (2001: 323-40), Dewey's own psychology was based primarily upon the neo-Hegelian philosophy of Thomas Hill Green. Backe's interpretation of Dewey's psychology leads to the conclusion that early Chicago functionalism should not be regarded as a unified theoretical approach.

12. Jim Garrison (2003) argues that Dewey's theory of emotions already presents the basis for the next theory of the reflex arc concept. However, he does not consider Mead's contribution to Dewey's functionalism to be so important.

13. Dewey's letter to James Rowland Angell (The Correspondence of John Dewey, Volume 1: 1871-1918, May 1893, electronic edition).

14. The notion of communicative gesture will be in the next years at the basis of Mead's and Dewey's theory of communicative interaction as the core of social development of meanings and Selves. It has to be noted that according to these authors communication is not intended to be linguistically (or propositionally) only, and meanings are not seen as mentalistic or ideational (as Pratten 2015 seems to argue), but rather as behavioral (Mead 1904: 377-8, 1934: 78-9; and Dewey 1929: 137). Meanings, in fact, are related to the dispositions to respond to certain vocal gestures which emotional attitudes are primitive expressions.

15. It is interesting to note that Panksepp (2001) has now advanced a similar explanation of the emotions. He addresses the need to complement neurophysiological terms with behavioral, 
psychological, and cerebral explanations of emotions, in a triangulation which he defines "affective neuroscience."

16. Some years later, Mead (1936: 392 ss.) defined Dewey's psychology as a "behavioristic psychology," distinguishing two ways of elaborating the general point of view of behaviorism. Watson's approach considers the process in an external way only, and Dewey's approach "carries with it the various values which we had associated with the term 'consciousness'." It is noteworthy that Watson conducted his doctoral studies at the University of Chicago under Angell's guidance, eventually defining his own behaviorism as "the only consistent and logical funcionalism" (Watson 1913: 166).

17. To be exact, the essay "Emotion and Instinct" remained unpublished until 2001.

18. See also Dewey (1894b: 158). The explanation of the rhythmical character of action represents the most important contribution of Mead's physiological perspective to Dewey's theory of emotions, according to whom: "all well-arranged or economical action is rhythmical."

19. As we find also in Veblen's 1906 essay "The Place of Science in Modern Civilization," he refers to the "pragmatic" school of psychologists accepting that "all learning is of a "pragmatic" character; that knowledge is inchoate action inchoately directed to an end; that all knowledge is "functional"; that it is of the nature of use. This, of course, is only a corollary under the main postulate of the latter-day psychologists, whose catchword is that The Idea is essentially active" (Veblen 1919: 5). We totally agree with Kilipinen's comparison of Veblen's words on pragmatic psychologists with his suggestion about the possible development of a new conception of human reasoning in such an endeavour as that of Kant's third Critique (Veblen 1884; see Kilpinen 1999: 196). However, I want to stress the distinction between the notion of idea as aim of an act (Dewey 1895: 170-1) and trascendental Aim of human beings (as in Kant's trascendental philosophy), even though Veblen argued to be not interested to teleological details of conduct, criticizing marginal utility economics based on such details (Veblen 1919).

20. Mead's "Untitled fragment on the relation between evolution, the development of intelligence, and the control of emotion, passion, or reflex action" (George Herbert Mead Collected Papers, Regenstein Library, University of Chicago, Box X, Folder 30).

21. Ibid.: 3 .

22. Ibid.: 6

23. Ibid.: 7. Cf. Dewey (1895: 185).

24. This is testified also in Dewey's review of Lester F. Ward's The Psychic Factors of Civilization in which Dewey claimed that: "The biological theory of society needs reconstruction from the standpoint of the recognition of the significance of intellect, emotion, and impulse" (Dewey 1894a: 210).

25. General value of habits are something "common to the generality of men" (Veblen 1919: 239).

26. Lawson challenges Hodgson's depiction of Veblen's account of habit (Hodgson 2004), according to which the notion of habit, which origin is rooted in the pragmatist philosophers and instinct psychologists, "is a propensity to behave in particular way in a particular class of situations" (Hodgson 2004: 652). Contrary to what Hodgson argues, Lawson (2015: 999-1002) suggests that the ideas of habits and of instituions as settled habits are derived to Veblen directly from Kant's philosophy. In my opinion, though Veblen was influenced by Kant thought, and in particular by Kant's Critique of Judgment, it is more plausible that his Kantian legacy has been mediated by his Peircean background. On this point see also Griffin (1998: 739-40).

27. Whilst after 1908 Veblen referred to McDougall's social psychology, it is plausible to hypothesize that his general interest in social psychology would have been influenced, at least in part, by the pragmatist and behavioristic conceptualization that he developed at Chicago. It is, in fact, thanks to a psychological idea Veblen assimilated in the period 1896-1900 that he found some "familiarity" with McDougall's social psychology. McDougall rooted individual consciousness in social instinct, highlighting the interaction between social and biological 
dimensions of the organic circuit. However, as we have seen, some years before Dewey and Mead elaborated the theoretical framework in which McDougall after inserted his work, in particular Mead's theorizing of the passage from the instinctive to symbolic stimuli as the basis of the qualitative distinction between emotion and interest. See in particular Veblen (1914: Ch.1.); Tworney 1998; and Dugger (1979: 430).

28. Cf. Maybarry (1969: 317 ss.). Tilman (1996: 93) pointed out that the ambiguity of meaning Veblen uses the notion of "instinct" would gathered from the ambiguous use James did in his Principles of Psychology. In effect, James defined instincts as: "the habits to which there is an innate tendency" (James 1890: 68). He also spoke of "instinctive impulses" (James 1890: 198).

29. Hence James' inferential, rather than ontological, use of the term 'soul' in the Principles of Psychology (James 1890: 3-4, 1892: 400).

30. For a discussion of the concept of habit in economic analysis see Waller 1988, and in sociology Camic 1986.

\section{ABSTRACTS}

In the following pages I shall sketch some thoughts on Veblen's implicit and explicit references to pragmatism and functional psychology, arguing that, besides Peirce and James, the functionalist theories and psychological experiments of the research group led by Dewey and Mead at the University of Chicago set the scene for Veblen's intellectual revolution. More precisely, whilst Veblen did not mention it explicitly, it is possible to find in his writings of the years 1896-1900 references to Dewey's notion of the "organic circuit" and to Dewey's and Mead's theory of emotion.*

This paper has three parts and three aims. In the first part, I outline Veblen's criticism of economic science and his proposal for a new evolutionary economics, paying particular attention to Veblen's implicit reference to Peirce's logic. In the second part, I single out Veblen's reference to Dewey's and Mead's works on functional psychology. In the third part, I will compare Mead's hypothesis of the genesis of social interests in emotions with the evolutionary economic theory sketched by Veblen.

* Tilman (1996: Ch 3) argued over pragmatic influences upon Veblen's ideas concerning the human mind. James and Dewey's functional psychology offered a psychological basis for his social theory. In my opinion, however, Veblen has been influenced by the Chicago School of functionalism more than by James' functionalism, in particular by Dewey's and Mead's ideas. Moreover, even if Tilman (1998) points out Dewey's intellectual debt to Veblen's idea, his references consist normally in a period later than that considered here.

\section{AUTHOR}

\section{GUIDO BAGGIO}

Università Pontificia Salesiana and Università di Roma Tre

guidobaggio[at]hotmail.com 